\title{
BUSINESS MODEL CANVAS JASA PENYAMBUNGAN BARU LISTRIK PADA PERUSAHAAN KELISTRIKAN DI INDONESIA
}

\author{
Danang Setiawan¹, Mirwan Surya Perdhana² \\ 1 Magister Manajemen, Fakultas Ekonomika dan Bisnis, Universitas Diponegoro \\ ${ }^{2}$ Magister Manajemen, Fakultas Ekonomika dan Bisnis, Universitas Diponegoro
}

\begin{abstract}
ABSTRAK
Tujuan dari penelitian kualitatif ini adalah untuk memahami Business Model Canvas jasa penyambungan baru listrik pada perusahaan PT PLN (persero) Unit Induk Distribusi Jawa Tengah dan D.I Yogyakarta (UID JTY) dan mengidentifikasi penyebab terjadinya keterlambatan penyambungan baru. Narasumber merupakan Manager bagian konstruksi dari 13 (tiga belas) Unit Pelaksana Pelayanan Pelanggan (UP3) / Area, narasumber merupakan salah satu pejabat struktural yang dipandang paling tahu dan terkait langsung dengan pekerjaan kontrak penyambungan baru listrik. Teknik pelaksanaan dengan metode Focus Group Discussion (FGD), terbagi menjadi 2 (dua) bagian pertanyaan, yakni pre test FGD dan wawancara FGD, dimana dalam pre test akan ditanyakan terkait value proposition dari layanan penyambungan baru pelanggan, setelah itu baru dilakukan FGD dari pertanyaan layanan penyambungan baru khususnya pada 3 (tiga) blok business model canvas (blok key activites, key partners dan key resources). Hasil penelitian dari coding wawancara pelaksanaan focus group discussion dengan para narasumber menyimpulkan bahwa faktor - faktor yang dominan terjadi dan berdampak pada terlambatnya penyambungan baru listrik PLN UID Jateng DIY adalah terkait ketersediaan material distribusi utama (MDU) kWh Meter dan kabel sambungan rumah di gudang UP3 dan ULP, terkendala juga akibat eksternal pelanggan seperti SLO (sertifikat laik operasi) dari Lembaga Inspeksi Teknik (LIT) terlambat terbit serta instalasi bangunan dari calon pelanggan tidak siap. Sehingga sembilan blok Business Model Canvas (BMC) dari layanan jasa penyambungan baru listrik dapat diidentifikasi dan penyebab utama keterlambatan penyambungan baru terdapat pada blok key activites dan key resources.
\end{abstract}

Kata Kunci: Business Model Canvas, Focus Group Discussion, Material Distribusi Utama, Lembaga Inspeksi Teknik, Sertifikat Laik Operasi, Perusahaan Kelistrikan

\section{PENDAHULUAN}

Sebagai perusahaan BUMN yang melayani kepentingan umum, pelayanan tenaga listrik yang terbaik kepada pelanggan dari PT PLN (Persero) harus selalu diberikan. Berbagai program kerja telah dilakukan PT PLN (Persero) Unit Induk Distribusi Jawa
Tengah dan Daerah Istimewa Yogyakarta melalui masing-masing area/unit pelaksana pelayanan pelanggan (UP3) dan unit layanan pelanggan (ULP) untuk meningkatkan kinerja pelayanan, sejalan dengan visi perusahaan korporasi PT PLN (Persero) holding.

${ }^{1}$ Corresponding author, Email: danangpln123@gmail.com 
Seiring dengan tumbuhnya daya beli masyarakat dan berdampak pada kegiatan ekonomi masyarakat yang lebih baik maka pasokan listrik ke pelanggan menjadi sangat dibutuhkan, apalagi PLN sebagai BUMN dibidang kelistrikan yang ditugaskan pemerintah sebagai pemegang izin usaha penyediaan tenaga listrik (IUPTL) yang berdasarkan undang-undang negara kesatuan republik indonesia (NKRI) nomor 30 tahun 2009 maka PLN dalam memberikan layanan terbaik seharusnya berkomitmen untuk terus melakukan perbaikan layanan, terkhusus untuk layanan penyambungan baru calon pelanggan

Berdasarkan latar belakang permasalahan diatas maka dapat kita rumuskan bahwa percepatan penyambungan baru listrik kepada calon pelanggan akan memberikan dampak positif bagi peningkatan citra perusahaan dan meminimalisir terjadinya kompensasi TMP (Tingkat Mutu Pelayanan). Pada peraturan menteri energi dan sumber daya mineral (ESDM) nomor 27 tahun 2017, pasal 4, disebutkan bahwa maka besaran tingkat mutu pelayanan tenaga listrik untuk indikator kecepatan hari pelayanan sambungan baru (HPL) tegangan rendah dilaksanakan dengan ketentuan paling lama: (a) 5 (lima) hari kerja tanpa perluasan jaringan; (b) 15 (lima belas) hari kerja dengan perluasan jaringan tegangan rendah; dan (c) 25 (dua puluh lima) hari kerja dengan penambahan trafo.

Sekaligus juga di dalam permen ESDM nomor 27 tahun 2017 dijelaskan terkait pemberian kompensasi. Jika realisasi tidak sesuai dengan deklarasi penetapan Tingkat Mutu Pelayanan (TMP) 5,15 dan 25 hari di setiap ULP maka kompensasi diberikan kepada konsumen dalam bentuk pengurangan tagihan listrik. Besaran nilai kompensasi ditentukan sesuai pasal 6 ayat 2 yakni sebagai berikut: (a) 35\% (tiga puluh lima persen) dari biaya beban atau rekening minimum untuk konsumen pada golongan tariff yang dikenakan penyesuaian tariff tenaga listrik (tariff adjustment) atau; (b) 20\% (dua puluh persen) dari biaya beban atau golongan rekening minimum untuk konsumen pada golongan tarif yang tidak dikenakan penyesuaian tariff tenaga listrik (tariff adjustment)

Berdasarkan latar belakang diatas, dapat disimpulkan bahwa di perusahaan PLN, sebagai contoh adalah Unit Induk Distribusi Jawa Tengah dan D.I Yogyakarta terdapat beberapa masalah diantaranya sebagai berikut: (a) Kondisi penyambungan baru belum optimal, dibuktikan dengan adanya pelanggan yang disambung melebihi tingkat standar mutu pelayanan yang ditetapkan (Deklarasi TMP); (b) Keterlambatan penyambungan akan berdampak pada revenue loss dari PLN yang diestimasikan sebesar Rp. 141 juta per tahun; (c) iset gap, yaitu masih terdapat gap antara praktek lapangan dan prosedur operasi baku/teori (type gap Action Knowledge Conflict dan Evaluation Void) sehingga dengan SOP (Standing Operation Procedure) saja ternyata tidak bisa menjelaskan permasalahan keterlambatan penyambungan baru listrik.

Apabila penyebab dari keterlambatan penyambungan ini dapat diidentifikasi, maka revenue yang hilang dapat diminimalisir. Untuk mengidentifikasi penyebab keterlambatan ini, digunakan tools yaitu Business Model Canvas. Business Model Canvas akan digunakan sebagai panduan dalam melaksanakan wawancara kualitatif untuk menggali sebenarnya apakah yang menyebabkan keterlambatan. Business Model Canvas memiliki 9 (sembilan) building block yang merefleksikan keseluruhan proses operasi. Pertanyaan penelitian dapat diidentifikasi sebagai berikut: (1) Bagaimana model bisnis jasa penyambungan baru listrik 
pada perusahaan PLN UID JTY?; (2) Apa yang menyebabkan keterlambatan penyambungan baru listrik?

\section{TELAAH PUSTAKA \\ Business Model Generation}

Business model generation (Pemodelan Bisnis) dan pemodelan proses sering digunakan secara bergantian dalam literatur sistem informasi, namun melayani tujuan yang berbeda, pemodelan proses menggambarkan bagaimana kegiatan penciptaan nilai dilakukan, pemodelan bisnis menggambarkan essensi dari bisnis dan memberikan pemahaman bagi pengguna dengan jelas tentang logika bisnis yang mendasari keberadaan entitas dan infrastruktur yang diperlukan untuk mengoperasikan konsep bisnis.
Kebutuhan pengguna model bisnis dapat dianalisis menurut dua dimensi yakni dimensi tingkat abstraksi yang diperlukan dan dimensi aspek tampilan. Tingkat abstraksi mengacu pada jumlah detail yang disampaikan oleh model bisnis. Sebuah model bisnis yang sangat abstrak akan memberikan gambaran dari bisnis. Sebuah model bisnis tingkat rendah akan berisi informasi rinci tentang unsur-unsur dari model bisnis dan asosiasi dengan satu sama lain . secara umum, pengguna eksternal model bisnis memerlukan model yang lebih abstrak dari pengguna internal, sistem informasi pengembang membutuhkan pandangan yang lebih rinci dibandingkan manajer bisnis (Salgado, Teixeira, Machado, \& Maciel, 2014).

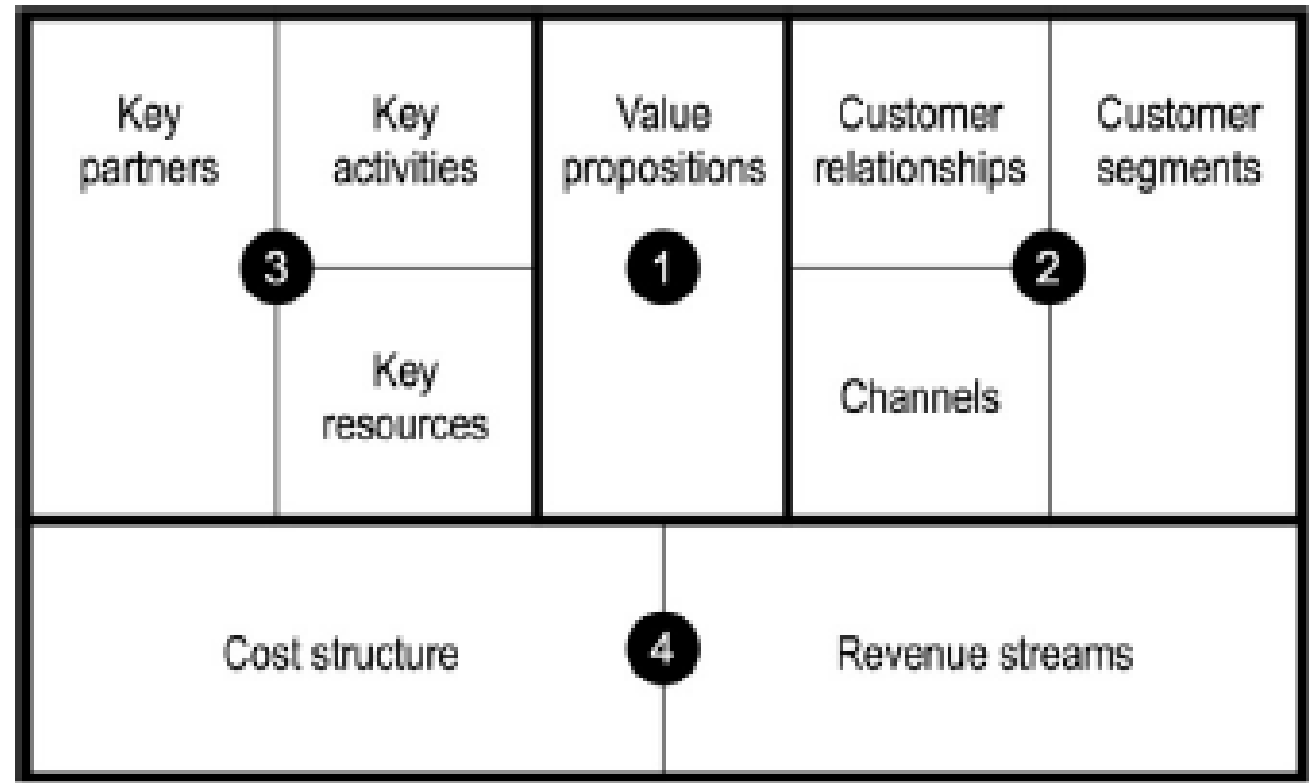

Note: 1 = Product; 2 = Customer interface; 3 = Infrastructure management; and 4 = Financial aspects.

Gambar 1. Blok Diagram representasi dari BMC 


\section{Business Model Canvas (BMC)}

Blok Diagram dari Business Model Canvas (BMC) diperkenalkan pertama kali oleh alexander osterwalder tahun 2005, aktivitas bisnis organisasi dipetakan dalam 9 (Sembilan) blok model. BMC digunakan untuk membangun bisnis yang kuat dan memiliki tujuan memetakan strategi perusahaan (Osterwalder, Pigneur, Smith, \& Movement, 2010). Ciri khas dari BMC adalah 9 (Sembilan) blok model yang menjadi satu kesatuan bisnis dan terkait satu sama lain, 9 (Sembilan) blok model tersebut adalah sebagai berikut: (1) Segmen pelanggan (Customers Segment); (2) Proposisi Nilai (Value Proposition); (3) Hubungan Pelanggan (Customer relationship); (4) Media (Channel); (5) Aliran Pendapatan (Revenue Stream); (6) Sumber Daya Utama (Key Resource); (7) Kegiatan Utama (Key
Activities); (8) Kemitraan Utama (Key Partnership); dan (9) Struktur Biaya (Cost Structure)

Keuntungan dengan adanya BMC adalah keseluruhan kekuatan dan kelemahan bisnis (SWOT Analysis) dapat cepat diketahui, proses analisa profit yang dihasilkan dan analisa kebutuhan perusahaan dilakukan secara cepat, pemetaan bisnis diketahui sejak dini tentang kelemahan perusahaan serta pemahaman kekuatan bisnis dilihat dari sudut pandang yang benar.

Blok business model canvas menggambarkan sistematika bisnis yang berjalan dan sehingga dapat digunakan sebagai pertimbangan manajemen untuk pengambilan keputusan pengembangan manajemen stratejik bisnis.

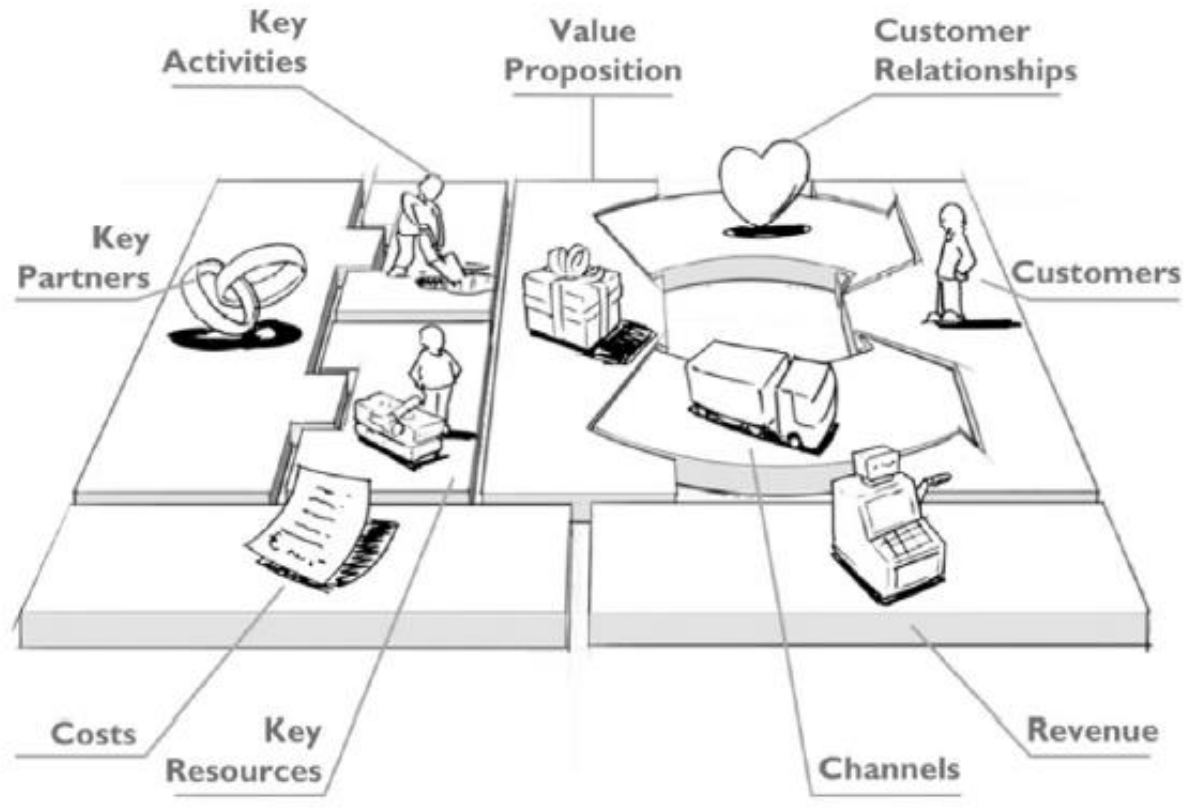

Gambar 2. Representasi Business Model Canvas (Osterwalder \& Pigneur,2009)

\section{METODE PENELITIAN}

Dalam penelitian ini, peneliti lakukan dengan Focus Groups Discussion menggunakan metode kualitatif yang mana di (FGD) dengan pegawai yang berhubungan 
langsung dengan pekerjaan di lapangan. FGD ini di bagi dalam empat sesi yang membahas masalah: (a) Penyelesaian Daftar Tunggu Permohonan Pasang Baru; (b) Penambahan Jumlah Pelanggan; (c) Hari Pelayanan (HPL) pasang baru berdasarkan TMP; (d) Pembahasan ketiga masalah dengan seluruh anggota tim.

Terdapat banyak pendekatan dalam metode kualitatif, dalam riset ini peneliti menggunakan pendekatan studi kasus. Penelitian studi kasus adalah pendekatan kualitatif yang mengeskplorasi kehidupan nyata, sistem terbatas kontemporer (kasus) atau beragam sistem terbatas (berbagai kasus), melalui pengumpulan data yang detail dan mendalam yang melibatkan beragam sumber informasi atau sumber majemuk (pengamatan, wawancara, bahan audiovisual, dokumen, dan berbagai laporan) dan melaporkan deskripsi kasus.(Creswell, 2015)

\section{HASIL DAN PEMBAHASAN}

Berdasarkan 15 (lima belas) pertanyan terbuka diatas, maka terjawab sudah pertanyaan penelitian dalam tesis ini, PT PLN Unit Induk Distribusi Jawa Tengah dan DI Yogyakarta merupakan unit organisasi yang mengelola 13 (tiga belas) Unit Pelaksana Pelayanan Pelanggan (Area), 1 (satu) Unit Pelaksana Pengatur Distribusi (UP2D) dan 1 (satu) Unit pelaksana proyek ketenagalistrikan provinsi Jawa Tengah dan Propinsi DIY, dalam kegiatan operasional penyambungan baru listrik di UID Jawa Tengah dan DIY mengalami permasalahan keterlambatan pemasangan baru.

Maka berdasarkan focus group discussion dengan para narasumber baik manager bagian kontruksi UP3, staff kontruksi UP3 serta ahli di bidang pengelolaan penyambungan menyimpulkan bahwa faktor- faktor yang dominan terjadi dan berdampak pada terlambatnya penyambungan baru listrik PLN UID Jateng DIY adalah sebagai berikut: (1) Material Kwh Meter, Kabel Sambungan Rumah (MDU) tidak tersedia di gudang UP3 dan ULP; (2) SLO dari LIT TR terlambat terbit; (3) Instalasi calon pelanggan tidak siap.

Setelah diketahui key activities dan key resources yang berdampak sebagai penyebab keterlambatan penyambungan baru listrik maka perusahaan PLN perlu menerapkan metode pengukuran kegiatan tersebut melalui strategi Balance scocecard (kartu stok berimbang). Dengan adanya balance scorecard maka kerangka kerja tindakan strategis dapat mengarahkan sasaran dan tindakan yang nyata untuk mencapai visi dan misi perusahaan (value proposition).

Empat perpektif dalam balance scorecard diantaranya perspektif finansial, perspektif proses bisnis internal, perspektif pelanggan dan perspektif pembelajaran dan pertumbuhan. Dari empat perspektif tersebut maka dimasukkan dalam target kinerja yang nantinya diberikan kepada setiap Unit pelaksana pelayanan pelanggan (UP3). Berdasarkan block diagram value proposition, bisa disimpulkan bahwa pada akhirnya anggota tim mengharapkan terwujudnya value proposition dari PLN, yakni percepatan penyambungan baru listrik sesuai tingkat mutu pelayanan (TMP) 5,15 dan 25 hari. sehingga diharapkan menjaga citra perusahaan tetap baik dan meningkatkan kepuasan pelanggan, semua unsur PLN tentunya harus menyelaraskan hati, pikiran dan tindakan sehingga target yang dibebankan dapat tercapai. Business Model Canvas jasa penyambungan baru listrik PLN UID JTY dapat dilihat pada Gambar 3. 


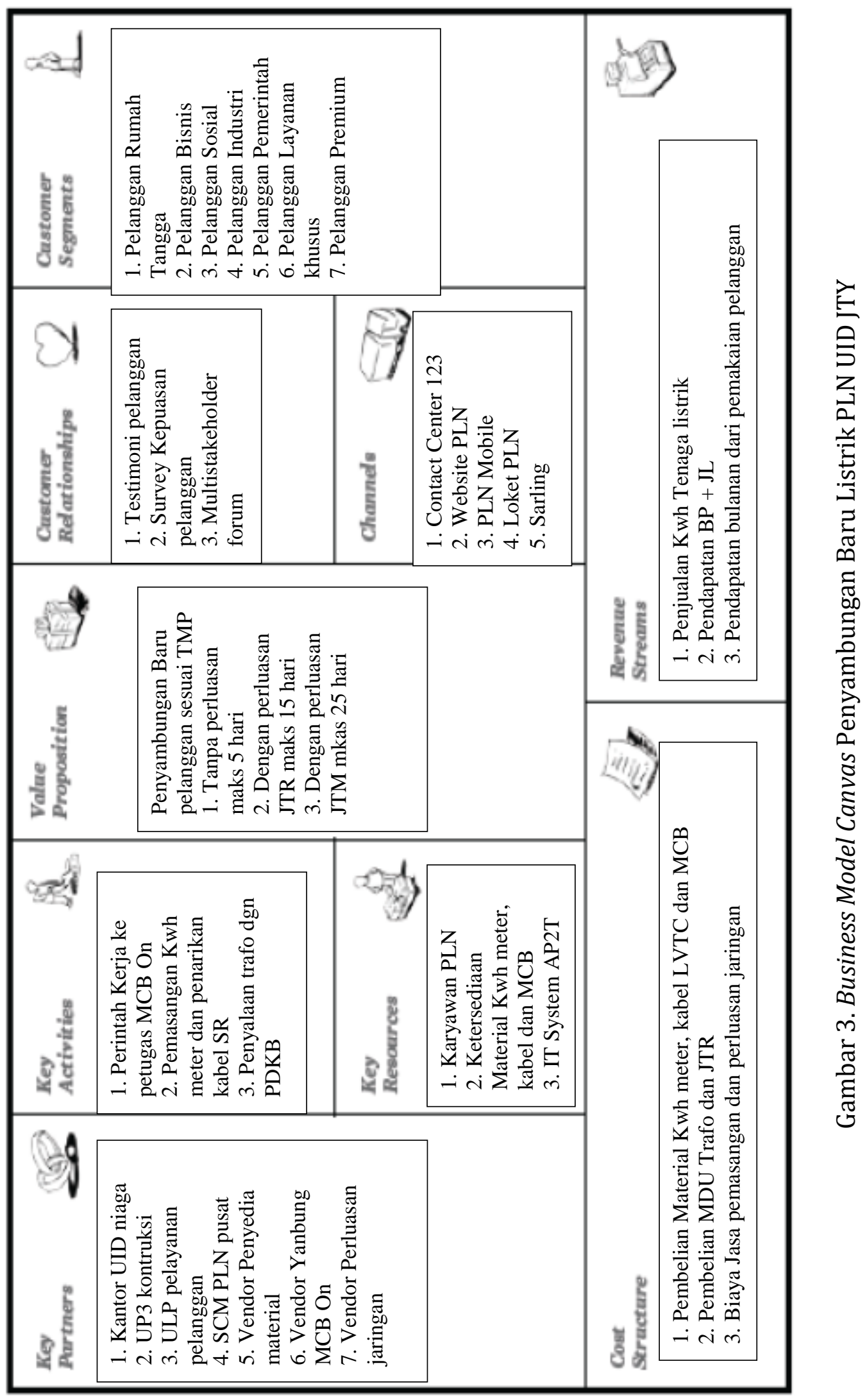




\section{KESIMPULAN DAN IMPLIKASI KEBIJAKAN}

Simpulan dan Implikasi manajerial dalam penelitian ini adalah pertama, meningkatkan kinerja suatu perusahaan kelistrikan yang bergerak dalam bidang usaha jasa layanan (services) dapat dilakukan dengan continues improvement pada kegiatan operasional pelayanan pelanggan, salah satunya dengan menjaga performa percepatan penyambungan baru listrik sesuai tingkat mutu pelayanan yang dideklarasikan 5,15,25 hari. Kedua, dari 9 (sembilan) blok Business model canvas dalam bisnis jasa penyambungan baru listrik PLN diketahui pada penelitian bahwa blok key activities berpengaruh dominan terhadap tercapainya value proposition yang ditetapkan perusahaan, sehingga nantinya berdampak kepada peningkatan penjualan tenaga listrik dan laba perusahaan, faktor internal yang dapat dikontrol oleh perusahaan adalah penyiapan material secara berkesinambungan, oleh karena itu SCM (suplay chain management), rantai pasok material, dari suplier sampai dengan terpasang di pelanggan perlu dilakukan kajian lebih mendalam. Ketiga, dalam mempertahankan pencapaian layanan penyambungan baru sesuai TMP 5,15,25 hari maka strategi yang penting disiapkan adalah terkait pemenuhan material pendukung penyambungan baru (Kwh Meter, Kabel dan MCB), berkoordinasi dengan Lembaga inspeksi teknik (LIT) Tegangan rendah (TR) dan komunikasi kepada calon pelanggan terkait kesiapan instalasi rumah.

\section{REFERENSI}

Cherbakov, L., Galambos, G., Harishankar, R., Kalyana, S., \& Rackham, G. (2005). Impact of service orientation at the business level. IBM Systems Journal, 44(4), 653-668. https://doi.org/10.1147/sj.444.0653

Creswell, J. W. (2015). Penelitian Kualitatif \& Desain Riset: Memilih di antara Lima Pendekatan. Yogyakarta: Pustaka Pelajar.

Dudin, M. N., Lyasnikov, N. V. evich, Leont'eva, L. S., Reshetov, K. J. evich, \& Sidorenko, V. N. (2015). Business model canvas as a basis for the competitive advantage of enterprise structures in the industrial agriculture. Biosciences Biotechnology Research Asia, 12(1), 887894. https://doi.org/10.13005/bbra/1736

Dvořáková, L., \& Faltejsková, O. (2016). Development of Corporate Performance Management in the Context of Customer Satisfaction Measurement. Procedia - Social and Behavioral Sciences, 230(May), 335-342. https://doi.org/10.1038/348494a0

ESDM, M. (2016). Permen ESDM No 28 Tahun 2016.

Frick, J., \& Ali, M. M. (2013). Business Model Canvas as Tool for SME, 142-149. https://doi.org/10.1007/978-3-642-41263-9_18

Lambert, S. (2008). for Business Model Research. EConference, 277-289. 
Laurea; Jukka Ojasalo and Katri Ojasalo. (2015). Service Logic Business Canvas Model Canvas : Implications for service business.

Mendagri. (2008). Permendagri Nomor 12 Tahun 2008, p. 282.

Menteri ESDM. (2017). Permen ESDM No 27 Tahun 2017.

Nur, A., Amanullah, A. A., Faizah, N., Aziz, A., Hanis, F. N., Hadi, A., \& Ibrahim, J. (2015). Comparison of Business Model Canvas (BMC) Among the Three Consulting Companies. ISSN International Journal of Computer Science and Information Technology Research ISSN, 3(2), 2348-1196. https://doi.org/10.1016/j.jssc.2009.07.035

Osterwalder, A., Pigneur, Y., Smith, A., \& Movement, T. (2010). Business Model Generation. Booksgooglecom (Vol. 30). https://doi.org/10.1523/JNEUROSCI.0307-10.2010

Plenter, F., Fielt, E., Hoffen, M., Chasin, F., \& Rosemann, M. (2017). Repainting the Business Model Canvas for Peer-To-Peer Sharing and Collaborative Consumption. In Proceedings of the 25th European Conference on Information Systems (ECIS), 2017, 2234-2249. Retrieved from http://aisel.aisnet.org/ecis2017_rp/142

Prawirosentono, S. (2008). Kebijakan Kinerja Karyawan (2nd ed.). Yogyakarta: BPFE.

Salgado, C. E., Teixeira, J., Machado, R. J., \& Maciel, R. S. P. (2014). Generating a business model canvas through elicitation of business goals and rules from process-level use cases. Lecture Notes in Business Information Processing, 194, 276-289.

Spreng RA ; Mackoy RD. (1996). An Empirical Examination of a Model of Perceived service quality and satisfaction.

Sugiono. (2005). Metode Penelitian Pendidikan (Pendekatan Kuantitatif, Kualitatif dan R\&D). Penerbit CV. Alfabeta: Bandung.

Sureshchandar, G. S., Rajendran, C., \& Anantharaman, R. N. (2002). The relationship between service quality and customer satisfaction ??? a factor specific approach. Journal of Services Marketing, 16(4), 363-379. https://doi.org/10.1108/08876040210433248

Wallin, J., Chirumalla, K., \& Thompson, A. (2013). Developing PSS Concepts from Traditional Product Sales Situation: The Use of Business Model Canvas. Proceedings of the 5th CIRP International Conference on Industrial Product-Service Systems, 263-274. https://doi.org/10.1007/978-3-642-30820-8_23 